\title{
The Fatty Acid Composition and Properties of Oil Extracted from Seeds of Carum roxburghianum Benth. (Radhuni)
}

\author{
B. K. Paul ${ }^{\mathrm{a}}$, M. N. Ahmed ${ }^{\mathrm{a}}$, G. C. Sahab ${ }^{\mathrm{b}}$ and S. K. Roy ${ }^{\mathrm{b} *}$ \\ ${ }^{a}$ Department of Chemistry, Jagannath University, Dhaka-1100 and \\ ${ }^{b}$ Chemical Research Division, BCSIR Laboratories, Dhaka-1205, Bangladesh
}

\begin{abstract}
Carum roxburghianum Benth. (Radhuni) seeds of three different places of Bangladesh were investigated to determine the fatty acid composition and physico-chemical properties of extracted oil. The seeds were found to contain oil ranging from 15.31 to $20.32 \%$. The percentage compositions of fatty acids were identified and quantified by Gas Liquid Chromatography (GLC). The saturated and unsaturated fatty acids in extracts were 4.95 to $6.27 \%$ and 93.73 to $94.89 \%$, respectively. Among six fatty acids identified in this study, oleic acid contributed the highest portion (76.44 to $79.16 \%)$, whereas, linoleic (1.38\%), linolenic (15.28 - 15.40\%), stearic $(0.70 \%)$, palmitic $(4.95-5.57 \%)$ and ecosenoic acid $(0.51-15.73 \%)$ together contributed the rest. Physico-chemical properties of the oil extracted were also investigated. The specific gravity, refractive index, optical rotation were recorded as 0.903 to 0.918 at $30^{\circ} \mathrm{C}, 1.465$ to 1.470 at $30^{\circ} \mathrm{C}$ and $+8.54^{\circ}$ to $+9.56^{\circ}$ at $26^{\circ} \mathrm{C}$, respectively. The chemical properties like saponification value (183.52 - 193.45), iodine value (80.99 - 120.90), peroxide value (23.25 - 36.16), acid value (143.84 - 162.99), ester value (48.12 - 62.03), percentage of unsaponifiable matter (3.56 - 6.51\%), Reicher-Meissel value (2.00 - 3.12), Polenske value (4.12 - 6.20) and Henher value (85.12 - 95.56) were determined. Overall Radhuni seeds oil can be considered as a good source of oleic acid.
\end{abstract}

Keywords: Carum roxburghianum, Radhuni seed oil, fatty acid composition, oleic acid, Gas Liquid Chromatography.

\section{Introduction}

Carum roxburghianum Benth. (locally known as Radhuni) belonging to the family Apiaceae (Umbelliferae) (Minosuke, 1958; Heinrich et al., 2003) is native to tropical Asia and also cultivated in Bangladesh, India and Indo-China. The people of this region cultivates it as pot herb and use it's seed to flavor curries. The herb Radhuni grows $90-95 \mathrm{~cm}$ high and is an annual winter crop. The seeds about 1/5 inches (1.5-3.0 $\mathrm{mm}$ ) long (Anonymous, 1976). In Bangladesh Radhuni Yield: 1.0-1.5 t/hac (Personal communication with Regional Spice Research Center, BARI at Joydebpur).

Radhuni seed is used as condiment, stimulant and carmine (Uphof et al., 1968). It is useful in hiccup, vomiting and pain in the bladder (Kirtikar and Basu, 1935) and forms an ingredient of carminative and stimulant preparations which are useful in dyspepsia and flatulence. It is often used in Indian cuisine, as a very strong spice with smell of parsley. A couple of pinches can flavor a curry (Joy et al., 2001). It is a con

\footnotetext{
* Corresponding author: E-mail: bishwagithp@yahoo.com
}

stituent of panch phoran (Bengali five spice) mixture (Alluri et al., 2005). Moreover, the Radhuni seed oil is used as scenting agents in detergents, soaps, air fresheners and insect repellents, whilst as an intermediate in the synthesis of perfume chemicals and as a pharmaceutical aid (Bakowski and Michalik, 1986).

Plant seeds are the most promising sources of lipid, a major constituent of human food. It provides essential fatty acids for body and serves as the structural material of cell membranes in all tissues (Saleh-E-In and Roy, 2007). The fatty acids or lipids class produced from any type of oil seed may vary with geographical location, cultivar, soil type, climate, moisture, temperature, maturity of the seed and agricultural practice (Galliard el al., 1975; Kinsella et al., 1975; Chu and Sheldon, 1979; Ching, 2000; Saleh-E-In and Roy, 2007). 
With the increasing demand of vegetable oils and spice in the country, the investigation on seeds of Radhuni has assumed to be of great importance.

The studies on fatty acid composition and other activities of the Radhuni oil are available (Gujral et al., 1953; Shahid et al., 2003). In the present study, Bangladeshi C. roxburghianum seeds have been considered to (a) estimate the chemical composition of extracted seed oil, (b) compare the quality and quantity of fatty acids and (c) evaluate whether the oil could be used in edible purpose and as pharmaceuticals aid.

\section{Materials and Methods}

\section{Plant materials}

Radhuni seeds were collected from Regional Spice Research Center at Joydebpur, Keranigonj in Dhaka and Regional Spice Research Center at Faridpur. The brownish green seeds were harvested in the month of March, 2009. The samples were cleaned to separate from dirt, sun-dried, steam-distilled to make it free from essential oil and again sun-dried.

\section{Extraction}

The essential oil free dried samples were powdered by a warring blender. About $100 \mathrm{~g}$ of crushed seed-cake was then subjected to extraction with petroleum ether (b.p. $40-60^{\circ} \mathrm{C}$ ) in a Soxhlet apparatus for $72 \mathrm{~h}$ to isolate oil from each variety with three replications. In each experiment, the mass filtered and filtrate was vacuum distilled to remove solvent completely. The yield of oils were calculated and stored in a refrigerator for further analyses using AOAC methods (Official Methods of Analysis, 1984).

\section{Physico-chemical study of the oil}

The physico-chemical properties of extracted oils of a particular place were determined with three replications using cited standard methods (Official Methods of Analysis, 1984; A Manual of Lab. Tech., 1976; British Pharmacopoeia, 2004; Kirk and Sawyer, 1991).

\section{Identification and quantification of fatty acids}

The fatty acid contents (qualitative and quantitative) were determined by GLC of methyl esters. The fatty acid methyl esters (FAMEs) were prepared by complete esterification (checked by TLC) of oil using $\mathrm{BF}_{3}-\mathrm{MeOH}$ complex (Official
Methods of Analysis, 1984; Metcalfe et al., 1966; Bannon et al., 1982; Saleh-E-In and Roy, 2007). Standard FAMEs (E. Merck) were used for the identification and quantification of the peaks.

For methylation, the lipid was at first, saponified with alcoholic sodium hydroxide, then cooled and diluted with water. After evaporation of alcohol, the acidified aqueous mixture was extracted with ether. Ether was then removed from etherial solution to get fatty acid mixture. The fatty acid mixture was esterified with $\mathrm{BF}_{3}-\mathrm{MeOH}$ complex. After esterificaton, the reaction mixture was dissolved in diethyl ether in a separating funnel and was washed with dilute sodium carbonate solution until the effervescence was ceased. It was then washed with water, dried over anhydrous sodium sulphate and finally ether was removed to get methyl ester mixture (Official Methods of Analysis, 1984; Metcalfe et al., 1966; Bannon et al., 1982; Saleh-E-In and Roy, 2007).

\section{Instrument and separation conditions}

The FAMEs were analyzed on a Trace GC ULTRA, Thermo Electron Corporation, Gas Chromatograph fitted with a flame ionization detector and an electronic integrator. An SE-54 quartz capillary column $(30 \mathrm{~m} \times 0.25 \mathrm{~mm}$ i.d. and $0.25 \mu \mathrm{m}$ film thicknesses) packed with $10 \%$ diethylene glycol succinate on 100-200 mesh solid support was used. Nitrogen was used as carrier gas at a flow rate of 1.5 $\mathrm{mL} / \mathrm{min}$. The separation was affected at $100^{\circ} \mathrm{C}-220^{\circ} \mathrm{C}$. The following temperature program was chosen in $\mathrm{GC}$ analyses: Initial temperature $150^{\circ} \mathrm{C}$, increasing at $7^{\circ} \mathrm{C} / \mathrm{min}$ to $260^{\circ} \mathrm{C}$ for $30 \mathrm{~min}$. The oven, injection and detection temperatures were fixed at $150^{\circ}, 180^{\circ}$ and $220^{\circ} \mathrm{C}$ respectively. The fatty acids were identified by comparison of relative retention times and peak positions of the chromatogram with that for the standard FAMEs. The amounts of fatty acids were calculated from the peak areas computed by LKB 2220 electronic recording integrator.

\section{Results and Discussion}

The comparative results of the physico-chemical properties and fatty acid compositions of Radhuni seeds oil of different places of Bangladesh are presented in Tables I and II, respectively. Seeds contained 15.31 to $20.32 \%$ fatty oil. The lowest amount of oil was found in Joydebpur sample (15.31\%) compared to $20.23 \%$ and $20.32 \%$ in Faridpur and Keranigonj samples, respectively. 
Table I: Physico-chemical properties of C. roxburghianum (Radhuni) seeds of different regions of Bangladesh.

\begin{tabular}{|c|c|c|c|}
\hline \multirow[t]{2}{*}{ Characteristics } & \multicolumn{3}{|c|}{ Values in the sample of } \\
\hline & Joydebpur & Keranigonj, Dhaka & Faridpur \\
\hline Oil yield (\%) & $15.31 \pm 0.12$ & $20.32 \pm 0.13$ & $20.23 \pm 0.33$ \\
\hline $\begin{array}{l}\text { Appearance at } \\
\text { Room temperature } 30^{\circ} \mathrm{C}\end{array}$ & \multicolumn{3}{|c|}{$\begin{array}{l}\text { A homogeneous, opaque, viscous oily liquid with dark greenish black color and } \\
\text { lighter than water }\end{array}$} \\
\hline Odor and taste & \multirow{2}{*}{\multicolumn{3}{|c|}{$\begin{array}{l}\text { Unpleasant spicy odor with bitter taste } \\
\text { Insoluble in water but freely miscible in chloroform, carbon tetrachloride, pet- } \\
\text { ether, n-hexane, diethyl ether and alcohol }\end{array}$}} \\
\hline Miscibility and solubility & & & \\
\hline Specific gravity at $30^{\circ} \mathrm{C}$ & $0.903 \pm 0.039$ & $0.918 \pm 0.027$ & $0.904 \pm 0.035$ \\
\hline Refractive index $[\eta]^{30^{\circ} \mathrm{C}}$ & $1.470 \pm 0.123$ & $1.465 \pm 0.093$ & $1.470 \pm 0.095$ \\
\hline Optical rotation $[\alpha]_{\mathrm{D}}{ }^{26^{\circ} \mathrm{C}}$ & $+9.03^{\circ} \pm 0.05$ & $+8.54^{\circ} \pm 0.04$ & $+9.56^{\circ} \pm 0.05$ \\
\hline Acid value & $162.99 \pm 1.50$ & $154.10 \pm 1.36$ & $143.84 \pm 0.30$ \\
\hline Ester value & $48.12 \pm 1.60$ & $56.25 \pm 1.35$ & $62.03 \pm 1.45$ \\
\hline Saponification value (mg KOH/g) & $193.45 \pm 0.30$ & $183.52 \pm 0.75$ & $189.30 \pm 0.85$ \\
\hline Unsaponifiable matter (\%) & $6.51 \pm 0.39$ & $4.23 \pm 0.79$ & $3.56 \pm 0.96$ \\
\hline Iodine value (Hanus method) & $120.90 \pm 0.79$ & $110.39 \pm 0.56$ & $80.99 \pm 0.98$ \\
\hline Peroxide value & $23.25 \pm 0.30$ & $36.16 \pm 0.30$ & $27.07 \pm 0.35$ \\
\hline Reichert Miessel (R.M.) value & $2.59 \pm 0.04$ & $3.12 \pm 0.05$ & $2.00 \pm 0.03$ \\
\hline Poleneske value & $5.07 \pm 0.93$ & $6.20 \pm 0.56$ & $4.12 \pm 0.53$ \\
\hline Henher value & $93.68 \pm 0.36$ & $95.56 \pm 0.49$ & $85.12 \pm 0.43$ \\
\hline
\end{tabular}

* Each value represents the average of three replicate analyses $\pm \mathrm{SD}$

The physico-chemical properties of the oil showed that the oils were in general opaque and viscous liquid of dark greenish black in color with an unpleasant spicy odor and bitter taste. It was freely miscible in chloroform, carbon tetrachloride, petroleum ether, n-hexane, diethyl ether and alcohol but immiscible with water.

The optical rotations were within $+8.54^{\circ}$ to $+9.56^{\circ}$ at $26^{\circ} \mathrm{C}$. The refractive indices (RI) varied from 1.465 to 1.470 at $30^{\circ} \mathrm{C}$ which were comparable to there of soybean oil $(1.466$ - 1.470) and rice bran oil (1.470 - 1.473) (Meyer, 1987; Lange, 1944; Mowla et al., 1990; Kirk et al., 1991). The refractive indices of the oils indicated that the oil contained fairly large amount of long chain unsaturated fatty acid (Mabaleha et al., 2004; Ali et al., 1998; Saleh-E-In and Roy, 2007).

Table II: Fatty acid composition (in wt \%) of C. roxburghianum (Radhuni) seeds of different regions of Bangladesh determined by GLC

\begin{tabular}{l|c|c|l}
\hline \multirow{2}{*}{ Name of fatty acid } & \multicolumn{3}{|c}{ Content (wt \%) in the sample of } \\
\cline { 2 - 4 } & Joydebpur & Keranigonj, Dhaka & \multicolumn{1}{c}{ Faridpur } \\
\hline Palmitic acid $\left(\mathrm{C}_{16: 0}\right)$ & $5.57 \pm 0.14$ & $5.11 \pm 0.12$ & $4.95 \pm 0.51$ \\
Stearic acid $\left(\mathrm{C}_{18: 0}\right)$ & $0.70 \pm 0.32$ & Not found & Not found \\
Oleic acid $\left(\mathrm{C}_{18: 1}\right)$ & $76.44 \pm 0.56$ & $79.16 \pm 0.23$ & $79.15 \pm 0.43$ \\
Linoleic acid $\left(\mathrm{C}_{18: 2}\right)$ & $1.38 \pm 0.52$ & Not found & Not found \\
Linolenic acid $\left(\mathrm{C}_{18: 3}\right)$ & $15.40 \pm 0.42$ & Not found & $15.28 \pm 0.18$ \\
Ecosenoic acid $\left(\mathrm{C}_{20: 1}\right)$ & $0.51 \pm 0.02$ & $15.73 \pm 0.09$ & Not found \\
\hline
\end{tabular}

\footnotetext{
* Each value represents the average of three replicate analyses $\pm \mathrm{SD}$
} 
The specific gravities of the oils were found within 0.903 to 0.918 at $30^{\circ} \mathrm{C}$, which indicated that the oil contained higher molecular weight fatty acids as well they were closer to those of olive oil $(0.914-0.918)$, cotton seed oil (0.917 0.918 ) and mustard oil (0.914 - 0.923) (Meyer, 1987; Lange, 1944; Mowla et al., 1990; Ching, 2000).

Properties of the oil such as acid value, iodine value and saponification value usually gives the structural, stability and quality information about the oils (Saleh-E-In and Roy, 2007). Saponification values were found within 183.52 to $193.45 \mathrm{mg} \mathrm{KOH} / \mathrm{g}$ indicating the presence of higher molecular weight fatty acids in the oils. High molecular weight fatty acids are not good for human health. In that sense, fats or oils having low saponification number should be preferred (Meyer, 1987). The saponification values were quite similar to the range of olive oil (185 - 196), corn oil (187 - 193), linseed oil (188 - 195) and cotton seed oil (189 - 199) (Meyer, 1987; Lange, 1944; Mowla et al., 1990; Ching, 2000; Jacobs, 2006; Nollet, 2004) which were typical $C_{16}$ and $C_{18}$ oils.

The extracted fatty oils had the iodine value within 80.99 to 120.90 which were almost similar to those for olive oil (79 $88)$, peanut oil (88 - 98), rapeseed oil (97 - 110), rice bran oil (92 - 109), cotton seed oil (99 - 121) and mustard oil (96 124) (Meyer, 1987; Lange, 1944; Mowla et al., 1990; Ching, 2000; Jacobs, 2006; Nollet, 2004). Iodine value is a measure the degree of unsaturation of fatty acids content of any fat or oil (as the value increases unsaturation increases). So, the result indicates that the oil possesses high unsaturation (Saleh-E-In and Roy, 2007). Therefore, the extracted oil possesses high proportion of higher unsaturated fatty acids.

Acid values of extracted oils were found to vary within $143.84-162.99$ indicating that the proportion of free fatty acid content was very high than those in edible oils like soybean oil (0.38 - 0.54), mustard oil (3.65 - 4.56) and palm oil (0.17 - 1.06) (Meyer, 1987; Lange, 1944; Mowla et al., 1990; Ching, 2000; Jacobs, 2006; Nollet, 2004). If the concentration of free fatty acid in a fat or oil is very high then the oil is hazardous for human health (Saleh-E-In and Roy, 2007). So, this oil cannot be used for edible purpose directly. However, it might be used for edible purposes after refining or for industrial purposes.

Ester numbers were found from 48.12 to 62.03 and peroxide values were found from 23.25 to 36.16 . Peroxide values showed that the oil had much free active oxygen enabling autoxidation of the oil (Mowla et al., 1990; Jacobs, 2006).

Unsaponifiable matter contents ranging from 3.56 to $6.51 \%$ were very much higher than those in any edible or non-edible oils like soybean oil $(0.015 \%)$, rapeseed oil $(0.02 \%)$, sesame seed oil $(0.02 \%)$ and palm oil $(0.012 \%)$ (Nollet, 2004; Mowla et al., 1990; Jacobs, 2006). The oil is supposed to be contaminated with mineral oil, higher aliphatic alcohols, sterols, pigments, hydrocarbons and sufficient amount of tocopherols (Patterson, 1983; Ali et al., 1998; Mowla et al., 1990; Jacobs, 2006). Tocopherols play important role as antioxidant (Patterson, 1983; Ali et al., 1998).

Reichert-Miessel (R.M.) values ranging from 2.00 to 3.12 were very much close to those in palm oil $(0.9-1.9)$ and corn oil (1.5 - 2.8) (Mowla et al., 1990; Jacobs, 2006; Meyer, 1987; Lange, 1944) and Poleneske values were found from 4.12 to 6.20 , palm kernel oil (4.20) and coconut oil (4.40) indicating that the oil had not much volatile components and low chain fatty acids (Mowla et al., 1990; Jacobs, 2006). Henher values from 85.12 to 95.56 showed that the oil's unsaponifiable matter and non-volatile components were very high and similar to palm oil (94 - 97) and corn oil (93 95) (Mowla et al., 1990; Jacobs, 2006; Nollet, 2004). The drying property of the extracted oils were examined to be non-drying in nature.

GLC analyses showed that oleic acid (76.44 to $79.16 \%$ ) was the major fatty acid found in the extract and the saturated fatty acids present in the oil sample were included palmitic acid (4.95 to $5.57 \%$ ) and stearic acid ( $0.70 \%)$ but stearic acid was found only in Joydebpur sample. Other unsaturated fatty acid linolenic acid (15.28 to $15.40 \%$ ) was not identified in Keranigonj sample and linoleic acid (1.38\%) was found only in Joydebpur sample. Ecosenoic acid was identified as $0.51 \%$ in Joydebpur sample and $15.73 \%$ in Keranigonj sample but was not identified in Faridpur sample. The oleic acid percentage was comparable to those in olive oil (65-85\%) and safflower oil (79.7\%). On the other hand, the palmitic acid content was almost comparable to those in the grape seed oil (4 - 11\%), linseed oil (4.8\%) and sunflower oil (4.29\%) (Nollet, 2004; Meyer, 1987; Lange, 1944; Mowla et al., 1990; Ching, 2000).

Healthful fats are lower saturated and higher mono-unsaturated fatty acid containing. Poly-unsaturated such as linolenic acid containing fats are pron to oxidation; whilst a high oleic acid helps to reduce the raised level of total plas- 
ma cholesterol without reducing the high density lipoprotein (HDL) cholesterol level (Francie et al., 1995).

As common vegetable oils usually contain $6-15 \%$ saturated fatty acids (Norton, 1989; Golfman and Bohme, 2001; Kamal Eldin and Yanishlieva, 2002) and Radhuni seeds oil contain 4.95 to $6.45 \%$ saturated fatty acids of the total oil, so, it is slightly higher in respect of the lower limit of the said percentage range but it is comparatively better for human consumption owing to its high percentages of the unsaturated fatty acids (93.73 to $94.89 \%$ ) especially the oleic acid ( $76.44 \%$ to $79.16 \%$ ) content.

\section{Conclusion}

Demand of quality oils and fats is increasing all over the world. To cope with the increasing demand of oils and fats the non-conventional sources are getting importance. The present study shows that Radhuni seeds contain 15.31 to $20.32 \%$ oil, and this oil is better than other vegetable oils with respect to health benefit. The fatty acid composition of the extracted oil is found in good agreement with the content of unsaturated acids (76.44 to $79.16 \%$ oleic acid and other 15.27 to $15.40 \%$ linolenic acid). But the deviation in the content of saturated acids is noticeable.

It is concluded that Radhuni seeds of Bangladeshi origin has got suitable nutritional properties and therefore, may be used as edible oil after proper refining. Otherwise, the extracted oil may be tapped as a source of oleic acid with an aim to be used in the food and pharmaceutical industries.

\section{Acknowledgements}

Authors are thankful to the Director, F. Begum (P.S.O), K. Nada (P.S.O), J. Rahman (S.S.O), S. M. M. Hasan (S.O), S. Ajij (S.O), M. M. Hossain (S.O), S. Ahmed (S.O), F. Jahan (R.C), M. M. Hossain (Jr. Tech.) and T. Islam (Jr. Tech.) of BCSIR Laboratories, Dhaka.

\section{References}

Anonymous (1976). A Manual of Laboratory Techniques (National Institute of Nutrition. Indian Council of Medical Research, Hyderabad, India), pp 1-5.

Ali M. M., Hussain M. G., Absar N. and Shahjahan M. (1998) Investigation on rice bran: composition of rice bran and its oil. Bang. J. Sci. Ind. Res., 33(2): 170-177.
Alluri V. K., Tayi V. N. R., Dodda S., Mulabagal V., HsinSheng T. and Gottumukkala V. S. (2005). Assessment of Bioactivity of Indian Medicinal Plants Using Brine Shrimp (Artemia salina) Lethality Assay. Int. J. Appl. Sci. Eng. 3 (2): 125-134.

Anonymous, Wealth of India (1976). A Dictionary of Indian Raw Materials and Industrial Products (CSIR, New Delhi), 10, pp 271-272.

Bakowski J. and Michalik H. (1986). Przydatnosc Niektorych Gatunkow Warzyw do Produkcji Suszow. Suitability of Several Vegetable Species for Drying. Biul. Warzywn., 12: 191-216 [in Polish].

Bannon C. D., Craske J. D., Hai N. T., Harper N. L. and O'Rourke K. L. (1982) Analysis of fatty acid methyl esters with high accuracy and reliability II. Methylation of oils and fats with boron trifluoridemethanol. J. Chromatogr., 247: 63-70.

Anonymous (2004). British Pharmacopoeia (B.P.) Package Ed. British Pharmacopoeia Commission (Stationery Office Books) IV(A): 248-250.

Ching K. C. (2000). Fatty Acids in Foods and their Health Implications. 2nd Ed. (Marcel Dekker Inc. Publisher, New York), pp 209-238.

Chu W. S. and Sheldon V. L. (1979). Soybean oil quality as influenced by planting site and variety. J. Am. Oil Chem. Soc., 56: 71-73.

Francie G. D., Pamele J. W., Linda M. P. and Thomas J. B. (1995). Fatty acid composition of oil from exotic corn breeding materials. J. Am. Oil Chem. Soc., 72(9): 981987.

Galliard T., Berkeley H. D. and Matthews J. A. (1975). Lipids of potato tubers. Effects of storage temperature on total, polar and sterol lipid content and fatty acid composition of potato tubers. J. Sci. Food Agric., 26: 1163-1170.

Golfman F. D. and Bohme T. (2001). Relationship between fatty acid profile and vitamin $\mathrm{E}$ content in maize hybrids (Zea mays L). Agr. Food Chem., 49: 49904994.

Gujral M. L., Kishor K. and Srivastava R. S. (1953) Chemical Study of Ajmod (Carum roxburghianum). 
Ind. J. Pharm., 15: 298-299.

Heinrich M., Barnes J., Gibbons S. and Williamson E. (2003). Families yielding important phytopharmaceuticals in Fundamentals of Pharmacognosy and Phytotherapy. (Churchill Livingstone, Edinburgh), pp 32-33.

Jacobs M. B. (2006) The Chemical Analysis of Foods Products. 3rd Ed., (CBS Publ.), pp 365-383.

Joy P. P., Thomas J., Mathew S. and Skaria B. P. (2001) Medicinal Plants. Tropical Horticulture. Vol. 2, 2nd Ed. (Naya Prokash, Calcutta, India), pp 449-632.

Kamal - Eldin A. and Yanishlieva N. V. (2002) N-3 Fatty Acids for Human Nutrition: Stability Concideration. Eur. J. Lipid Sci. Technol., 104: 825-836.

Kinsella J. E., Posati L., Weihrauch J. and Anderson B. (1975) Lipids in foods: problems and procedures in collating data, CRC Crit Rev. Food Technol., 5: 299324.

Kirk S. R. and Sawyer R. P. (1991). Composition and Analysis of Foods. 9th Ed. (Longman, Scientific and Technical Press, Essen. UK), pp 617-620.

Kirtikar K. R. and Basu B. D. (1935). Indian Medicinal Plants. 2nd Ed. (Lalit Mohan Basu Publications, Dehra Dun, Allahabad, India), pp 624.

Lange N. A. (1944). Handbook of Chemistry, 14th Ed. (Hand book Publishers Inc., Sandusky, Ohio), pp 678.

Mabaleha M. B. and Yeboah S. O. (2004). Characterization and compositional studies of the oils from some legume cultivars, Phaseolus vulgari, grown in Southern Africa. J. Am. Oil Chem. Soc., 81(4): 361364 .

Metcalfe L. D., Schmitz A. A. and Pelka J. R. (1966). Rapid preparation of fatty acid esters from lipids for gas chromatographic analysis. Anal. Chem., 38: 514-515.

Meyer L. H. (1987). Food Chemistry 1st Ed.(CBS Publ. and Distr., Delhi, India), pp 12-64.
Minosuke H. (1958).Umbelliferae of Asia (Excluding Japan). (Botanical Institute, Kyoto University, Kyoto, Japan) pp 1:182.

Mowla G., Sheick N. M. and Kamal A. S. M. (1990). Hand Book on Edible Oils and Fats with Special Reference to Bangladesh 1st Ed. (University of Dhaka, Dhaka, Bangladesh), pp 9-172.

Nollet L. M. L. (2004). Hand book of Food analysis, Physical Characterization and Nutrient Analysis (Food Science and Technology) 2nd Ed. Vol-1. (Marcel Dekker Inc. Publisher, New York, USA), pp 221-274.

Norton G. (1989). Nature and Biosynthesis of Storage Protams, in Oil Crops of the World. G. Robbenlen; R. K. Downey and A. Ashri Ed. (McGraw - Hill: New York) pp 165-191.

Anonymous (1984). Official Methods of Analysis 14th Ed. (Association of Official Analytical Chemist. Sydney, Williams. Arlington, USA), pp 503-532.

Patterson H. B. W. (1983). Hydrogenation of fats oils. (Applied Science Publishers, London and New York), pp 184.

Saleh-E-In M. M. and Roy S. K. (2007). Studies on Fatty Acid Composition and Proximate Analyses of Anethum Sowa L. (Dill) Seed. Bang. J. Sci. Ind. Res., 42(4): 455464.

Shahid M., Muhammad S., Muhammad Y. and Naeem K. M. (2003). Lipid Studies of Carum roxburghianum seeds. Nat. Prod. Sci., 9: 200-203.

Uphof J. C. (1968). Dictionary of Economic Plants. 2nd Ed. (Verlag Von J. Cramer, Lehre, Germany), pp 591.

Received : April 05, 2009;

Accepted : August 04, 2010 